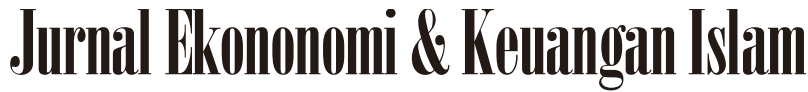

\author{
Available at http://journal.uii.ac.id/index.php/jeki
}

\section{Effect of productive zakat program on the improvement of welfare in Sragen regency}

\author{
Abdul Haris Romdhoni \\ STIE AAS Surakarta, Surakarta, Indonesia \\ e-mail: harisromdhoni27@gmail.com
}

\section{Keywords:}

Capital, income, consumption and welfare improvement.

\section{DOI:}

10.20885/JEKI.vol4.iss1.art5

\begin{abstract}
This study aims to determine the effect of capital, income and consumption on improving the welfare of the poor in Sragen regency. The data of this study were obtained through interviews and questionnaires distributed to community of LAZISMU Sragen. Data collection method used in this study is accidental sampling with samples as much as 90 mustahiq. The variables used in this study are productive zakat for welfare as a dependent variable; capital, income and mustahiq consumption as independent variables. Analytical technique used is multiple linear regression. The results of this study indicate that capital, income and consumption have an influence on the level of community welfare, but the capital has a greater influence than the income and consumption of society.
\end{abstract}

\begin{abstract}
Abstrak
Penelitian ini bertujuan untuk mengetahui pengaruh modal, pendapatan dan konsumsi terhadap tingkat kesejahteraan masyarakat miskin di Kabupaten Sragen. Data penelitian ini memperoleh melalui wawancara dan menyebar kuisioner pada komunitas LAZISMU Sragen. Metode pengumpulan data mengunakan accidental sampling dengan sampel sebanyak 90 mustahiq Adapun variabel yang digunakan dalam penelitian ini adalah variabel zakat produktif untuk kesejahteraan sebagai variabel dependen, sedangkan modal, pendapatan dan konsumsi mustahiq sebagai variabel independen. Teknik analisis yang digunakan adalah dengan regresi linier berganda. Dari hasil oleh data menunjukkan bahwa modal, pendapatan dan konsumsi memiliki pengaruh terhadap tingkat kesejahteraan masyarakat, namun modal memiliki pengaruh lebih besar dibanding dengan variabel pendapatan dan konsumsi masyarakat.
\end{abstract}

\section{Background}

Islam is a universal and integral religion. It is said universal because his teaching touches various aspects of life. While it is said integral because it consists of a whole teaching as an unity, such as the afterlife, spiritual, individual and social matters. Thus, the teachings of Islam will be related to each other that is complementing, perfecting and strengthening.

One of the concerns of religion and the State is the problem of poverty. The problem of poverty is an economic phenomenon that always accompanies the development process. Various debates about the causes of poverty, the size and solution that may be applied to the welfare of the community are a form of concern for the rising number of poor people that will result in a large negative impact on society.

Experts conclude that there are three causes of poverty: firstly, due to limited resources, the second is the low quality of human resources, the third is the lack of access to capital which causes less run of business and low production level of goods and services. The three causes of poverty are the task of all parties, both government and society in an effort to alleviate poverty (Rusli et al. 2013).

The influence of zakat on society and Islamic economy is very significant. In zakat, there is an attitude of empathy to the poor and the needy proactive action for public welfare. This is clearly reflected by its allocation as mentioned in QS. At-Taubah: 60. "Zakah expenditures are only for the poor and for the needy and for those employed to collect [zakah] and for bringing hearts together [for Islam] and for freeing captives [or slaves] and for those in debt and for the cause of Allah and for the [stranded] traveler - an obligation [imposed] by Allah. And Allah is Knowing and Wise.".

The above verse mentions (based on Al-Qur'an and its translation published by the Department of Religious Affairs of the Republic of Indonesia), that zakat is for the eight (8) groups mentioned above which arefakir (needy), miskin (poor), amil (those in charge of administer zakat), mualaf (just converted to Islam), gharim (those who are in debt), ibnusabil (those who are travelling that is not against Sharia and in need of 
help), fi sabilillah (people who fight in Allah's way) and riqab (slaves). Of the eight groups above, fakir miskin (the poor) is the object of this study.

Zakat given to mustahik (beneficiaries) in general is consumptive charity that is to meet the daily needs, but less help them for the long term. Since zakat in its use is consumptive, the money or daily necessities given will soon run out and they will return to live in a state of fakir (needy) and miskin (poor). Departing from that reality, contemporer scholars argued that zakat given to mustahik can be used for productive purpose in order to give added-value for a business by increasing its capital. The rotation of property generated through the distribution of zakat will contribute to the building of various economic activities within a society. Therefore, the poor, the poor, can sometimes develop zakat property for various results of effort, skill, or small business so as not to return to the conditions of begging and the pressure of poverty

To support the economic development of Indonesia, it is required to have the management of productive zakat that can empower the community. That by giving productive zakat is expected to be able to guide and assist zakat mustahik (recipients) in their business activities. The guidance given can also be his religious and religious intellectual coaching in order to increase the quality of his faith and his religion.

The number of poor people in Indonesia in March 2012 reached 29.13 million people or 11.96 percent of the total population of Indonesia (BPS, 2012). Efforts to alleviate poverty require resources that are not small, both human and material resources. The government itself has created a poverty alleviation program and allocates substantial funds that are formulated annually in the APBN. However, the whole program has not been fully effective.

In relation to the above poverty, if associated with zakat as a means of poverty alleviation, zakat in Indonesia has the potential as a tool to alleviate poverty that exists. It has been studied by Centre of PBB Studies UIN Syarif Hidayatullah (2005) estimating Islamic philanthropy potential of Rp 19.3 trillion (0.8\% of GDP in 2004 which is around Rp 1,656,516.8 billion). While a study conducted by BAZNAS- IRTI IDB (Firdaus et.al. 2012) found the potential of zakat in Indonesia reached up to Rp 217 trillion (3.4\% of GDP in 2010). While research Wibisono (2015) found the potential of zakat Indonesia reached up to Rp 106, 6 trillion. With such potential, it is appropriate for stakeholders to manage zakat seriously.

The potential of zakat mentioned above is a challenge for zakat amil agencies in maximizing their performance in building the trust of Muslims to be aware and willing to meet their zakat obligations, so that zakat fund can be used to alleviate poverty which becomes parameter to be classified as mustahik. The existence of productive zakat program becomes the means to alleviate poverty, by converting mustahik to muzaki in a certain period. In addition, Muslims who have not paid their zakat can immediately be invited to pay zakat through the institutions of amil zakat or zakat agency which is nearby and available.

Thus, hopefully zakat can alleviate poverty in Indonesia, while strengthening the society's economy. The success of zakat in poverty alleviation does not come easily, but the program of the managers (either in the form of Amil Zakat Agency (managed by the Government) or in the form of Amil Zakat Institute (managed by the community). With that background, this study will examine the extent to which the effectiveness of zakat program has been implemented.

Based on the above background, the formulation of the problem in this study is as follows; Firstly, does the capital affect the improvement of the welfare of the poor in Sragen? Secondly, does the income affect the improvement of the welfare of the poor in Sragen? Thirdly, does consumption have an effect on the improvement of prosperity of poor people in Sragen? Fourthly, do capital, income and consumption affect the improvement of the welfare of the poor in Sragen?

Zakat is one of the important pillars of Islamic teachings. Etymologically, zakat has the meaning of the word developing (an-namaa), sanctifying (at-thaharatu) and blessing (al-barakatu). While terminologically, zakat means the removal of some property with certain conditions to be given to certain groups (Mustahik) with certain requirements as well. (Hafidhuddin, 2002).

According to Darajat (1991) zakat comes from "zakka" which means holy, blessed, grows and praises. While terminologically zakat is a certain amount of property that is required by Allah SWT to be handed to people who are entitled to receive it, in addition to the definition of spending money in a certain amount itself. Zakat comes from the word tazkiyah which means to purify. Therefore, zakat means to purify property and soul. Based on this understanding zakat maal serves to clean the possessions of wealthy people (Razak, 1996).

While the Ministry of Religious Affairs through www.kemenag.go.id explains that zakat is a property/possession that must be set aside by a Muslim or a body in accordance with the provisions of religion, in order to be given to people who deserve it. Based on the definition of the Ministry of Religious Affairs of the Republic of Indonesia above, zakat was not only applicable to individuals but also to agencies/institutions. In addition, the Ulama should now begin to conceptualize and develop zakat for institution.

Productive zakat is zakat managed in a productive way, which is done by giving business capital to fakir and miskin as the recipient of zakat and then developed to meet their life needs in the future (Asnainu, 
2008). Productive Zakat is clearly different from consumptive zakat, because the distribution of consumptive zakatis in form of direct funding such as donation to fulfill the basic needs of the recipient (mustahik) including meals, clothing, education fees and others related to daily needs. In other words, consumptive zakat is for disposable needs, while productive zakat will give a multiplier effect because of the rotation that can produce and keep running.

Productive zakat is zakat which is given to mustahik as capital to run an economic activity that can improve economic condition and productivity potency of mustahik (Qadir, 2001). The existence of productive zakat is reinforced by El-Din (in Beik, 2009) which attempts to analyze the allocative functions and zakat stabilizers in the economy. It is stated that the allocative function of zakat is expressed as a tool or instrument to combat poverty. However, in the pattern of distribution, zakat is not only given in the form of consumer goods but also in the form of production goods. This is done when mustahik has the capacity and ability to process and perform production activities. In addition, it is necessary to encourage the distribution of zakat in the form of equity, which is expected to give a wider impact on economic conditions.

The utilization of zakat also needs to be done towards long-term investment. It can be transformed into several forms, firstly zakat is distributed to maintain work incentives or earn their own income among the poor. Secondly, part of the collected zakat, at least $50 \%$ is used to finance productive activities to the poor, such as the use of zakat to finance various activities and the training of productive skills, the provision of working capital or initial capital assistance. If such a zakat distribution can be implemented, it will greatly assist government programs in alleviating poverty, income equality, and narrowing the gap between rich and poor (Jamal, 2004).

Yusuf Al-Qardhawi (in Nawawi, 2010) states that the Islamic government is allowed to build factories or companies from zakat fund and then ownership and profits are used for the benefit of the poor, so that their needs can be met throughout the ages.

Strengthening the above statement Permono (1992) describes the utilization of productive zakat is about the requirements for properties that must be charged zakat include elements: al-maliyat or al-iqtisadiyat (economic element), al-nama 'or al-istinma' (productive element or can be used for productive purpose), al-milk al-tam (perfectly owned), al-kharij'an al hajah al-asliyyah (out of primary needs), tamam al nisab (perfect for one nisab), al-salamahmin al-dain (safe from debt), and haulan al haul au tamam al hasad (reached one year or dry harvest)

Zakat is a mahdah worship that has both individual and social impact. Individual impact, a person who is able and willing to pay zakat means to be free of his servitude to the property. By paying zakat also someone is not individualistic because conscious there is a right that must be given his property to the rightful.

While from the social aspect, with zakat, the property is not only spinning to the capable people, but also the wealth can be a means to make people prosperous and alleviate poverty, so that with the existence of zakat someone will be helped, which finally have the opportunity for economic justice rights.

Zakat also includes a detailed order of worship, therefore zakat has its own term and condition including haul (minimum period of time) and nishab (minimum size of property owned to be obligated for zakat).

Jauch and Glueck (1989) state the strategy is a unified, broad and integrated plan that links the company's strategic advantage with environmental challenges, designed to ensure that the company's main objectives can be achieved through proper implementation by the organization.

According to Schendel et.al (1985) describes there are four levels of strategy. The levels of strategy are:

a. Enterprise Strategy. This strategy is concerned with community responses. Every organization has a relationship with the community. Society is a group that is outside the organization, where the organization really works and strives to provide a good service to the demands and needs of the community.

b. Corporate Strategy. This strategy is related to the mission of the organization, so it is often called a grand strategy that covers the field that is cultivated by an organization. How the mission can be done is also important, it requires strategic decisions and strategic planning that each organization deserves.

c. Business Strategy. Strategies at this level describe how to seize the market in the community. All that is intended to be able to obtain strategic benefits that at the same time able to support the development of the organization to a better level.

d. Functional Strategy. This strategy is a support strategy and to support the success of other strategies.

Based on the above understanding that the strategy is long term, it is necessary to formulate a strategy regarding the process of preparing the steps forward. In Poerwodarminto (1999), welfare according to Indonesian dictionary derived from the word prosperous that has the meaning of safe, prosperous and survived (apart from all kinds of disorders, difficulties and so on). While the word prosperous comes from the Sansekerta "catera" which means umbrella. In the context of welfare, "catera" is a prosperous person who is free from poverty, ignorance, fear, or anxiety, so that his life is safe and secure, both physically and mentally (Fahrudin, 2012). 
Prosperity is always associated with the wealth, where the higher the productivity the higher the income generated. Other measures of welfare can also be seen from non-wealth as stated by Primary and Mandala, (in Widyastuti: 2012) through education, health and nutrition, freedom of choice and better guarantees of the future.

The view of general public, a prosperous family may be able to send their family members into educational insas high as possible. Similarly, if the higher level of education a person will bring his family more prosperous for getting reciprocity like a well-established job and adequate income. According to Rozana Himaz (in Widyastuti: 2012), higher education allows them to gain higher profits too, since education can increase income through the quality of workers. As explained by Kuncoro (1997: 124) this is due to access to jobs with high salaries both in government and private sector depending on the high level of education.

On the other side, welfare, according to al-Ghazali (in Rohman, 2010), can be defined as the achievement of benefit (mashlahat). Welfare itself is the preservation of the purpose of shari'a (Maqashid alShari'ah), where man can not experience happiness and inner peace but after the real well-being of all human beings in the world through the fulfillment of spiritual and material needs. In order to achieve the goal of wisdom 'in order to realize the benefit, he elaborated on the sources of welfare, namely: the maintenance of religion, soul, mind, descendant and wealth.

According to the Center for Assessment and Development of Islamic Economics/P3EI (in Sardar and Nafik, 2016: 394), welfare according to Islam includes two meanings; Firstly, holistic and balanced welfare, i.e the adequacy of wealth supported by the fulfillment of spiritual needs and includes the individual and the social. The human figure consists of physical and mental elements, so happiness must be thorough and balanced between the two. Similarly, humans have both individual and social dimensions. Man will be happy if there is a balance between himself and his social environment. Secondly, welfare in the world and the hereafter (falah), because man is not only living in the world only, but also in the world after death (akhirat). The sufficiency of wealth in the world is shown in order to obtain sufficiency in the afterlife. If this ideal condition is not achieved then prosperity in the afterlife would be preferred, because it is something that is eternal and more valuable (valuable) than the life of the world.

Poverty is a classic problem that is always faced by every country. Poverty seems to be a vicious cycle that is hard to find at the end of the base, so that when it breaks the chain of poverty, many nervous states will start from which direction or field. Like a disease, poverty must be "diagnosed" for what causes poverty, so that poverty therapy can be addressed properly. In Indonesia poverty is also an acute problem that every change of regime, there is always a story every episode that is packaged in such a way as the interested parties.

Korten (in Hikmat, 2004) states that there are three foundations for making structural and normative changes in people-centered development; firstly, focusing government policy thinking and action on creating conditions that encourage and support people's efforts to meet their own needs, and to solve their own problems at the individual, family, and community levels. Second, developing the structures and processes of organizations that function according to the rules of the organization system. Thirdly, develop territorially organized production-consumption systems based on local ownership and control principles. And, poverty alleviation that can be taken is by following steps (Agussalim, 2009): increase business intensity, knowledge, skills, physical and health access, access to capital for business, and natural resources and information access.

Islamic Guide for Zakat in Alqur'an; firstly. a command to collect zakat for purifying wealth and soul as stated in Surah At-Taubah Verse 103. Secondly, a command to pay zakat from one's earning as stated in Surah Al-Baqarah Verse 267. Thirdly, a command to pay zakat to be given for 8 groups of recipients as stated in Surah At-Taubah Verse 60. And, fourthly, a command to perform shalat and pay zakat in general as stated in Surah Al-Baqarah Verse 43. In the Hadits; firstly, hadits Bukharî and Muslim about a perfection element which builds Islam. Secondly, hadits Bukharî and Muslim to fight people who do not pay zakat. And, Thirdly, hadits Muslim aboutzakat/sedekah as burhân (proof).

From the description both from Alqur'an and Hadith, it is clear that zakat occupies a very crucial role. Zakat can purify the soul or spirituality of the culprit, simultaneously charity will clean up the mixed treasure of the unclean elements, where the prohibition is beyond the consciousness of the owner.

With zakat, if managed with a mandate, professional and sincere will bring for the needy, so that the equal distribution of income that often found in Developing Country, as in Indonesia will be slightly reduced. Zakatn will bring in the peace of mind for the managers (amiil), because they work in the name of the religion of Allah SWT. This is where the actual firmness in the collection of zakat for the authorities is tested. In one history that a capable person who does not want to pay zakat, it is worth fighting. Of course, how the government in a Muslim country to formulate so that zakat can really enter and exit, collected and smoothly distributed, so that zakat can improve the welfare of Muslims.

In addition to the legal basis from Qur'an and Hadith, Indonesia has a positive legal basis about zakat. The regulations on zakat contained in the positive law are: Firstly, law No. 23 Year 2011 about Zakat, Infak and Sedekah. Secondly, law of Government of Republic of Indonesia No. 14 Year 2014 about Implementation of 
Law No. 23 Year 2011 on Management of Zakat. Thirdly, decree of Ministry of Religious Affairs, Republic of Indonesia No. 114 Year 2014 about Formation of Province BAZNAS. And, fourthly, decree of Dirjen Bimbingan Masyarakat Islam dan Urusan Haji No. D/291 Year 2000 about Technical Guidance on Zakat Management.

\section{Research Method}

This research is including field research (field research) by using descriptive quantitative approach. This research type is quantitative research by using interview method and primary data from LAZISMU Sragen. The variables used in this study are variables empowering productive zakat as an independent variable and income/capital mustahik as a dependent variable which is then tested by different test.

This research was conducted by taking the location in LAZIS Muhammadiyah (LAZISMU) Sragen as research location because zakat management in Sragen is relatively successful and has relatively poor population. Population is the totality of all objects or individuals that have certain characteristics, clear and complete to be researched. The population in this study is all mustahik LAZISMU Sragen. While the sample is part of the population taken through certain ways that also have certain characteristics, clear, and complete that are considered to represent the population (Hasan, 2002). The appropriate sample size in the study is between 30 to 500 and when the sample is divided into categories, the total sample size for each category is at least 30 (Sugiyono, 2013).

The method used is through simple random sampling method, which is choosing a random sample based on existing data. To answer this research question, the data source in this research is primary data, primary data is internal data (Kuncoro, 2003) that is data obtained from direct field source.

This study uses data collection methods with techniques/methods of observation, interviews, and documentation (Sugiono, 2008): firstly, observation is to conduct direct observation and recording systematically towards the focus of the problems studied systematically, in this case observed directly in the field. Secondly, in depth interview, Interviews are methods of collecting data obtained through in-depth conversations or interviews conducted by two parties: interviewers who are applying and being interviewed (interviewee) who provide answers to the question (Subadi, 2011). And, thirdly, documentation, this data collection technique is also known as documentation research which collects data related to the focus of research originating from its main source (research object) such as relevant documents or archives (Arikunto, 1998).

The approach used in this study is a quantitative approach to analyze the measurement of economic phenomena which is a combination of economic theory (information financial statements), mathematical models and statistics that are classified in certain categories by using certain tables to facilitate in analyzing by using the program SPSS 20.0 for windows. Analytical technique used is with multiple linear regression.

Multiple linear analysis is used for the relationship between one dependent variable with more than one independent variable. Multiple linear regression method is used to determine whether there is a significant influence of one dependent variable and more than independent variable.

Multiple regression analysis to know influence between independent variable is productive zakat with variable dependent that is level of prosperity. The model of the relationship if prepared with a linear regression equation is as follows:

$$
\mathrm{Y}=\alpha+\beta_{1} \mathrm{X}_{1}+\beta_{2} \mathrm{X}_{2}+\beta_{3} \mathrm{X}_{3}+\varepsilon
$$

Note: $\mathrm{Y}=$ Productive Zakat for Welfareness, $\mathrm{A}=$ constant, $\mathrm{B}=$ regression coefficient is the number of change of dependent variable due to the change of independent variable, $\mathrm{X}_{1}=$ capital, $\mathrm{X}_{2}=$ income, and $\mathrm{X}_{3}=$ consumption

\section{Research Result}

\section{Validity Test}

The result of validity test is as follows:

Table 4.8. The Result of Validity Test on Capital

\begin{tabular}{ccccc}
\hline No & Statement & $\mathrm{r}_{\text {count }}$ & $\mathrm{r}_{\text {table }}$ & Note \\
\hline 1 & M1 & 0,637 & 0,207 & Valid \\
2 & M2 & 0,804 & 0,207 & Valid \\
3 & M3 & 0,803 & 0,207 & Valid \\
\hline
\end{tabular}

Source: Data processed, 2017. 
Table 4.8 above shows that all items of variable of capital statement are declared valid, this is proved by obtaining correlation coefficient value $\left(\mathrm{r}_{\text {count }}\right)>0,207$.

Table 4.9. The Result of Validity Test on Income

\begin{tabular}{ccccc}
\hline No & Statement & $\mathrm{r}_{\text {count }}$ & $\mathrm{r}_{\text {table }}$ & Note \\
\hline 1 & $\mathrm{P} 1$ & 0,677 & 0,207 & Valid \\
2 & $\mathrm{P} 2$ & 0,808 & 0,207 & Valid \\
3 & $\mathrm{P} 3$ & 0,754 & 0,207 & Valid \\
\hline \multicolumn{5}{l}{ Source: Data processed, 2017. }
\end{tabular}

Table 4.9 above shows that all items of income statement are declared valid, this is proved by obtaining correlation coefficient value $\left(\mathrm{r}_{\text {count }}\right)>0,207$. The value of 0.207 is obtained from the $r_{\text {table }}$ value with $N=90$.

Table 4.10. The Result of Validity Test on Consumption

\begin{tabular}{ccccc}
\hline No & Statement & r count & rtable & Note \\
\hline 1 & K1 & 0,630 & 0,207 & Valid \\
2 & K2 & 0,818 & 0,207 & Valid \\
3 & K3 & 0,804 & 0,207 & Valid \\
4 & K4 & 0,741 & 0,207 & Valid \\
\hline \multicolumn{5}{l}{ Source: Data processed, 2017. }
\end{tabular}

Table 4.10 above shows that all items of consumption statement are declared valid, this is proved by obtaining correlation coefficient value $\left(\mathrm{r}_{\text {count }}\right)>0,207$. The value of 0.207 is obtained from the $r_{\text {table value with }}$ $\mathrm{N}=90$.

Table 4.11. The Result of Validity Test on Welfare Enhancement

\begin{tabular}{ccccc}
\hline No & Statement & r $_{\text {count }}$ & rtable & Note \\
\hline 1 & TK1 & 0,742 & 0,207 & Valid \\
2 & TK2 & 0,724 & 0,207 & Valid \\
3 & TK3 & 0,742 & 0,207 & Valid \\
4 & TK4 & 0,755 & 0,207 & Valid \\
5 & TK5 & 0,331 & 0,207 & Valid \\
6 & TK6 & 0,524 & 0,207 & Valid \\
7 & TK7 & 0,524 & 0,207 & Valid \\
8 & TK8 & 0,462 & 0,207 & Valid \\
\hline Source: Data processed, 2017. & &
\end{tabular}

Table 4.11 above shows that all of welfare statements declared valid, this is proved by obtaining the value of correlation coefficient $\left(\mathrm{r}_{\text {count }}\right)>0.207$. The value of 0.207 is obtained from the $\mathrm{r}_{\text {table }}$ value with $\mathrm{N}=90$.

\section{Reliability Test}

Reliability test to the questionnaire on each research variable is as follows:

Table 4.12. The Result of Reliability Test

\begin{tabular}{clcl}
\hline \multirow{2}{*}{ No } & \multicolumn{1}{c}{ Variable } & $\begin{array}{c}\text { Cronbach's } \\
\text { Alpha }\end{array}$ & Note \\
\hline 1 & Capital & 0,614 & Reliable \\
2 & Income & 0,605 & Reliable \\
3 & Consumption & 0,741 & Reliable \\
4 & Welfare Enhancement & 0,720 & Reliable \\
\hline \multicolumn{2}{l}{ Source: Data processed, 2017. }
\end{tabular}

Based on table 4.12 above, it can be shown that all values of capital, income, consumption, health, education, and welfare are greater than 0.6 , so that capital, income, consumption, health, education, welfare can be declared reliable. 


\section{Normality Test}

The result of normality test as follows:

Table 4.13. The Result of Normality Test

One-Sample Kolmogorov-Smirnov Test

\begin{tabular}{|c|c|c|}
\hline & & $\begin{array}{l}\text { Unstandardized } \\
\text { Residual }\end{array}$ \\
\hline \multicolumn{2}{|l|}{$\mathrm{N}$} & 90 \\
\hline \multirow[t]{2}{*}{ Normal Parameters ${ }^{\mathrm{a}} \mathrm{N}$} & Mean & .0000000 \\
\hline & Std. Deviation & .97622032 \\
\hline \multirow{3}{*}{$\begin{array}{l}\text { Most Extreme } \\
\text { Differences }\end{array}$} & Absolute & .129 \\
\hline & Positive & .108 \\
\hline & Negative & -.129 \\
\hline \multicolumn{2}{|c|}{ Kolmogorov-Smirnov Z } & 1.222 \\
\hline \multicolumn{2}{|l|}{ Asymp. Sig. (2-tailed) } & .101 \\
\hline ation is I & Normal. & \\
\hline
\end{tabular}

Source: Data processed, 2017.

The result of Asym value. Sig in table 4:13 obtained value of 0.101 , this result when compared with the probability of 0.05 then larger, so it can be concluded that the research data is normally distributed.

\section{Multicollinearity Test}

The results of data calculations obtained value of Variance Inflation Factor (VIF) as follows:

Table 4.14. The Result of Multicollinearity Test

\begin{tabular}{ccc}
\hline Variable & VIF & Note \\
\hline Capital & 1,514 & No multicolinearity \\
Income & 1,744 & No multicolinearity \\
Consumption & 1,157 & No multicolinearity \\
\hline Source: Data processed, 2017 &
\end{tabular}

Source: Data processed, 2017.

Table 4.14 above shows that all values of Variance Inflation Factor (VIF) $<10$, so it can be concluded in this regression model does not occur symptoms of multicollinearity is the correlation between independent variables.

\section{Heteroskedasticity Test}

Heteroskedasticity test is done by looking at the value of significance after held regression with absolute residual on the dependent variable as follows:

Table 4.15. The Result of Heteroskedasticity Test

\begin{tabular}{lcc}
\hline \multicolumn{1}{c}{ Variable } & Sig & Note \\
\hline Capital & 0,391 & No heteroskedasticity \\
Income & 0,899 & No heteroskedasticity \\
Consumption & 0,057 & No heteroskedasticity \\
\hline Source
\end{tabular}

Source: Data processed, 2017.

Table 4.15 above shows all the significance value greater than 0.05 , so that variable capital, income, consumption, health and education does not occur symptoms of heteroscedasticity. 


\section{Multiple Linear Regression Test}

The results of multiple linear regression analysis can be seen as follows:

Table 4.16. The Result of Multiple Linear Regression Test

\begin{tabular}{|c|c|c|c|c|c|}
\hline \multicolumn{6}{|c|}{ Coefficients $^{\mathrm{a}}$} \\
\hline \multirow[b]{2}{*}{ Model } & \multicolumn{2}{|c|}{$\begin{array}{l}\text { Unstandardized } \\
\text { Coefficients }\end{array}$} & \multirow{2}{*}{$\begin{array}{c}\begin{array}{c}\text { Standardized } \\
\text { Coefficients }\end{array} \\
\text { Beta }\end{array}$} & \multirow[b]{2}{*}{$\mathrm{t}$} & \multirow[b]{2}{*}{ Sig. } \\
\hline & B & Std. Error & & & \\
\hline $1 \quad$ (Constant) & 3.299 & 1.087 & & 3.033 & .003 \\
\hline Capital & .703 & .077 & .374 & 9.113 & .000 \\
\hline Income & .208 & .075 & .122 & 2.760 & .007 \\
\hline Consumption & .090 & .040 & .080 & 2.241 & \\
\hline
\end{tabular}

a. Dependent Variable: Welfare

Source: Data processed, 2017.

Based on table 4:16 above multiple linear regression equation can be arranged as follows: $\mathrm{Y}=3,299+0,703 \mathrm{X} 1+0,208 \mathrm{X} 2+0,090 \mathrm{X} 3+\varepsilon$

Based on multiple linear regression equation can be interpreted as follows:

a. The constant value is 3.299, this indicates that if the variable of capital, income, consumption, health, and education if considered constant (0), then the value of improving the welfare of the poor in Sragen is 3,299.

b. The regression coefficient of capital $(b \neg 1)$ is positive value of 0.703 . This means that if capital is increased one unit with record of income, consumption, health and education variable is considered constant, it will increase the value of improvement of prosperity of poor society in Sragen equals to 0,703 .

c. The regression coefficient of income $(b \neg 2)$ is positive at 0.208 . This means that if income is increased by one unit with capital, consumption, health, and education is considered constant, it will increase the value of improving the prosperity of poor people in Sragen by 0,208.

d. The regression coefficient of consumption $(b \neg 3)$ is positive value of 0,090 . This means that if consumption is increased by one unit with capital, income, health, and education are considered constant, it will increase the value of improving the prosperity of the poor in Sragen by 0,090 .

\section{T-test}

The Result of T-test is as follows:

Tabel 4.17. The Result of T-test

\begin{tabular}{lcccc}
\hline \multicolumn{1}{c}{ Variable } & $\mathrm{t}_{\text {count }}$ & $\mathrm{t}_{\text {table }}$ & Sig. & Conclusion \\
\hline Capital & 9,113 & 1,992 & 0,000 & $\mathrm{H}_{1}$ accepted \\
Income & 2,760 & 1,992 & 0,007 & $\mathrm{H}_{2}$ accepted \\
Consumption & 2,241 & 1,992 & 0,028 & $\mathrm{H}_{3}$ accepted \\
\hline \multicolumn{2}{l}{ Source: Data processed 2017} & &
\end{tabular}

Source: Data processed, 2017.

a. $\quad$ Based on table 4.17 above note that the capital's tcount $=9,113$ with probability of 0.000 , when compared with $t_{\text {table }}(1,992)$ then $t_{\text {count }}>t_{\text {table }}$ and $\rho<0.05$. This indicates that $H_{1}$ is accepted, it means that capital affects the improvement of prosperity of poor people in Sragen.

b. The income'st count $=2,760$ and the probability is 0,007 , compared with $t_{\text {table }}(1,992), t_{\text {count }}>t_{\text {table }}$ and $\rho$ $<0,05$. This indicates that $\mathrm{H}_{2}$ is accepted, it means that income affects the improvement of prosperity of poor people in Sragen.

c. Consumption obtained $t_{\text {count }}=2,241$ and probability equal to 0,028 , when compared with ttable $(1,992)$ then $\mathrm{t}_{\text {count }}>\mathrm{t}_{\text {table }}$ and $\rho<0,05$. This indicates that $\mathrm{H}_{3}$ is accepted, meaning that consumption affects the improvement of prosperity of poor people in Sragen. 
F-test

\begin{tabular}{|c|c|c|c|c|c|}
\hline \multicolumn{6}{|c|}{ ANOVA $^{b}$} \\
\hline Model & $\begin{array}{l}\text { Sum of } \\
\text { Squares }\end{array}$ & Df & $\begin{array}{c}\text { Mean } \\
\text { Square }\end{array}$ & $\mathrm{F}$ & Sig. \\
\hline $\begin{array}{ll}1 & \text { Regressio } \\
n\end{array}$ & 821.138 & 5 & 164.228 & 162.645 & $.000^{\mathrm{a}}$ \\
\hline Residual & 84.818 & 84 & 1.010 & & \\
\hline Total & 905.956 & 89 & & & \\
\hline
\end{tabular}

F-test results can be seen from the value of $\mathrm{F}_{\text {count }}$ in ANOVA table (appendix 9) is obtained $\mathrm{F}_{\text {count }}$ of 162,645 and sig. 0,000. This result is larger when compared with $F_{\text {table }}$ (at df 5,84 obtained $F_{\text {table }}$ value $=$ $2,37)$.

Thus, it can be concluded that capital, income, and consumption have a significant effect together to improve the prosperity of poor people in Sragen.

\section{Coefficient of Determination Test $\left(\mathbf{R}^{2}\right)$}

The coefficient of determination $\left(\mathbf{R}^{2}\right)$ is used to measure the percentage of variation of the dependent variable which can be explained by the independent variables present in the model. Results calculation for the value of $\mathrm{R}$ Square $\left(\mathbf{R}^{2}\right)$, obtained the coefficient of determination $\mathbf{R}^{\mathbf{2}}=0.906$ or $90.6 \%$.

This means the ability of independent variables consisting of capital, income, consumption, health, and education in explaining the dependent variable is improving the welfare of the poor in Sragen by $90,6 \%$; the rest $(100 \%-90,6 \%=9,4 \%)$ is influenced by other variables outside the model not examined in this study.

\section{Conclusion}

Based on the results of research on the effect of productive zakat on improving the welfare of the poor in Sragen can be concluded as follows Capital affects the improvement of the welfare of the poor in Sragen. This is obtained from the $\mathrm{t}$ count $=9,113$ and the probability of 0.000 , when compared with $\mathrm{t}$ table $(1,992)$ then $\mathrm{t}_{\text {count }}>\mathrm{t}_{\text {table }}$ and $\rho<0,05$. This indicates that $\mathrm{H} 1$ is accepted, it means that capital affects the improvement of prosperity of poor people in Sragen.

1. Income affects the improvement of the welfare of the poor in Sragen. It is obtained from tcount $=2,760$ and probability equal to 0.007 , when compared with ttable $(1,992)$ then $t_{\text {count }}>t_{\text {table }}$ and $\rho<0,05$. This indicates that $\mathrm{H} 2$ is accepted, it means that income affects the improvement of prosperity of poor people in Sragen.

2. Consumption affects the improvement of the welfare of the poor in Sragen. It is obtained from tcount $=2,241$ and probability equal to 0,028 , when compared with ttable $(1,992)$ then $t_{\text {count }}>t_{\text {table }}$ and $\rho<0,05$. This indicates that $\mathrm{H} 3$ is accepted, meaning that consumption affects the improvement of the welfare of the poor

3. Capital, income, and consumption affects the improvement of the welfare of the poor in Sragen. It is obtained from the value of $\mathrm{F}_{\text {count }}$ of 162.645 and sig. 0,000. This result is larger when compared with Ftable (at df 5,84obtained $F_{\text {table }}$ value $=2,37$ ). So it can be concluded that the capital, income and consumption, have a significant effect together to improve the welfare of the poor in Sragen.

Based on the above conclusions, the suggestions that the authors propose to the parties involved in this study are as follows, firstly. LAZISMU Sragen should pay more attention to variable of capital, income, and consumption because all variables can influence improvement of prosperity of poor society in Sragen.

Secondly, LAZISMU Sragen can provide entrepreneurship management training and business school that simple and applicative. In addition, it can also provide assistance to the peripheral communities such as street children, as well as to the real sector such as small and medium micro enterprises (UMKM) or home industry.

Thirdly, in terms of empowerment of zakat, LAZISMU Sragen can work together with universities in the realm of community service in order to synergize between academic excellence and community empowerment. 


\section{References}

Agussalim. (2009). Mereduksi Kemiskinan. Makasar: Nala Cipta Litera dan Pusat Studi Kebijakan dan Manajemen Pembangunan Universitas Hasanuddin.

Arikunto, S. (1998), Prosedur Penelitian, Suatu Pendekatan Praktek, Jakarta: Rieneka Cipta.

Asnainu, (2008). Zakat Produktif dalam Perspektif Islam. Bengkulu: Pustaka Pelajar.

Beik, I. S. (2009), Analisis Peran Zakat Dalam Mengurangi Kemiskinan: Studi Kasus Dompet Dhuafa Republika, Jurnal Pemikiran dan Gagasan - Vol II

Darajat, Z. (1991), Dasar-Dasar Agama Islam, Jakarta: Bulan Bintang.

Fahrudin, A, (2012) Pengantar Kesejahteraan Sosial, Bandung: Refika Aditama.

Hafidhuddin, D. (2002). Zakat dalam Perekonomian Modern. Jakarta: Gema Insani Press

Hasan, M.I (2002), Pokok-Pokok Materi Statistik 2 (Statistik Inferensif). Jakarta: Bumi Aksara

Hikmat, H, (2004). Strategi Pemberdayaan Masyarakat. Bandung: Penerbit Humaniora

Jamal, M. (2004). Pengelolaan Zakat oleh Negara Untuk Memerangi Kemiskinan. Jakarta: Koprus

Jauch L.R. \& Glueck, W. F., (1989), 'Manajemen dan Strategis Kebijakan Perusahaan', Jakarta: Erlangga.

Kuncoro, M (2003), Metode Riset Untuk Bisnis Dan Ekonomi; Bagaimana Meneliti Dan Menulis Tesis, Jakarta: Erlangga , (1997). Ekonomi Pembangunan Teori, Masalah dan Kebijakan. Yogyakarta: UPP AMP YKPN.

Nawawi, I. (2010) Zakat dalam Perspektif Fiqih Sosial dan Ekonomi, Surabaya; Putra Media Nusantara

Permono, S.H. (1992) Pendayagunan Zakat Dalam Rangka Pembangunan Nasional, Pustaka Firdaus: Jakarta

Poerwodarminto,W.J.S. (1999), Kamus Umum Bahasa Indonesia, Jakarta: Balai Pustaka.

Qadir, A., (1998). Zakat dalam Dimensi Mahdah dan Sosial. Jakarta: Raja Grafindo Persada.

Razak, N. (1996), Dienul Islam, Bandung: Al Ma’arif

Rohman, A. (2010). Ekonomi Al-Ghazali, Menelusuri Konsep Ekonomi Islam dalam Ihya' Ulum al-Din. Surabaya: Bina Ilmu.

Rusli., Hamzah, A \& Syahnur, S (2013). Analisis Dampak Pemberian Modal Zakat Produktif terhadap Pengentasan Kemiskinan Di Kabupaten Aceh Utara, Jurnal Ilmu Ekonomi, 1(1), 56-63

Sardar, Z \& Nafik, M, (2016), Kesejahteraan Dalam Perspektif Islam Pada Karyawan Bank Syariah, Jurnal Ekonomi Syariah Teori dan Terapan. 3(5), 391-401

Schendel, D \& Charles, H. (1985). Pengambilan Keputusan Stratejik untuk Organisasi Public dan Organisasi Non Profit. Jakarta: Grasindo.

Subadi, T. (2011), Metode Penelitian Kualitatif, Cet. I, Surakarta: MUP UMS.

Sugiyono. (2013) Metode Penelitian Administrasi, Bandung: Alfabeta

Widyastuti, A (2012). Analisis Hubungan antara Produktifitas Pekerjaan dan Tingkat Pendidikan Pekerja terhadap Kesejahteraan Keluarga di Jawa Tengah Tahun 2009, Economics Development Analysis Journal, 1(2), 1-11 